\title{
Combining MRI with PET for partial volume correction improves image-derived input functions in mice
}

Eleanor Evans ${ }^{1 *}$, Guido Buonincontri ${ }^{1}$, David Izquierdo ${ }^{2}$, Carmen Methner ${ }^{3}$, Rob C Hawkes $^{1}$, Richard E Ansorge ${ }^{4}$, Thomas Kreig ${ }^{3}$, T Adrian Carpenter', Stephen J Sawiak ${ }^{1,5}$

From PSMR14: 3rd Conference in PET/MR and SPECT/MR

Kos Island, Greece. 19-21 May 2014

'Wolfson Brain Imaging Centre, University of Cambridge, Cambridge, UK
Kinetic modelling in PET requires the arterial input function (AIF), defined as the time-activity curve (TAC) in plasma. This measure is challenging to obtain in mice due to low blood volumes, resulting in a reliance on image-based methods for AIF derivation. We present a comparison of PET- and MR-based region-of-interest (ROI) analysis to obtain image-derived AIFs from the left ventricle (LV) of a mouse model. ROI-based partial volume correction (PVC) was performed to improve quantification.

MRI and dynamic PET images were obtained from a recent study investigating treatment effects in 12 mice following myocardial infarction [1], where half the mice received a new treatment and half did not. Prospectively gated MRI (4.7T Bruker BioSpec, FLASH TR/TE 400/3ms, spatial resolution $140 \mu \mathrm{m}$ in $1 \mathrm{~mm}$ slices) were acquired prior to PET acquisition (approx. $25 \mathrm{MBq}{ }^{18} \mathrm{~F}$-FDG bolus, 45 minute emission listmode acquisition reconstructed with 3DRP in four cardiac frames) on a split-magnet PET camera [2]. Images were co-registered using SPMMouse [3] (see Figure 1).

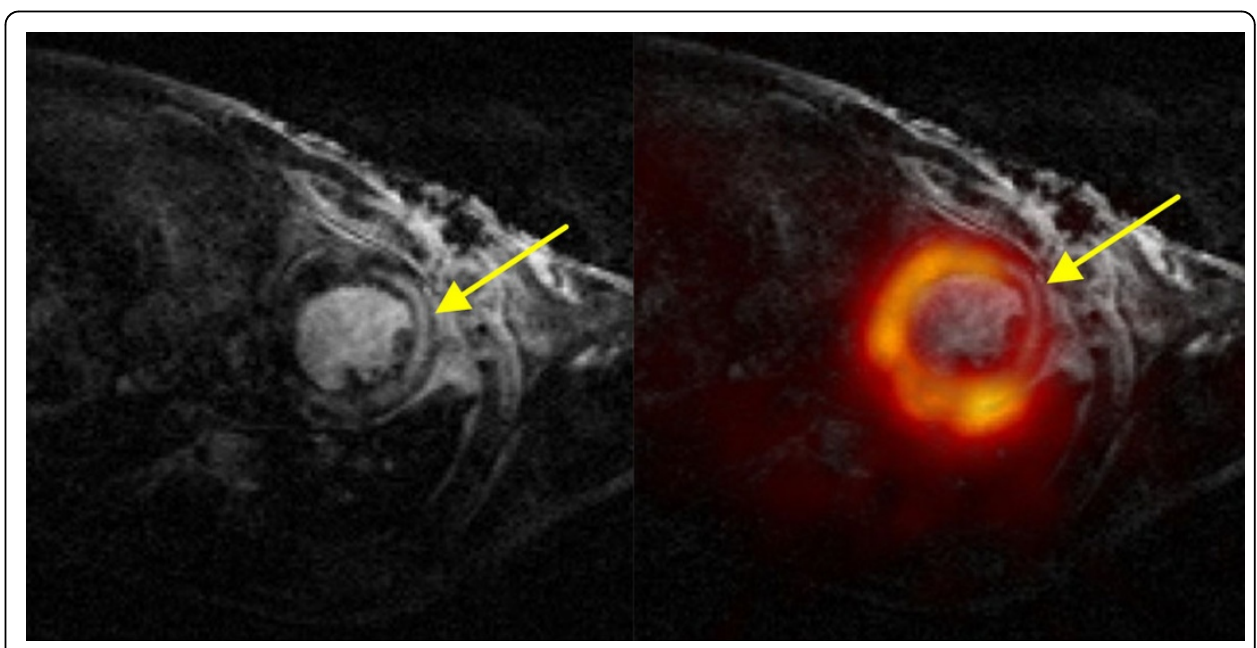

Figure 1 Mouse heart MR (left) and fused with ${ }^{18} \mathrm{~F}-\mathrm{FDG}$ static PET (right). Arrow indicates infarcted region.

(C) 2014 Evans et al; licensee Springer This is an Open Access article distributed under the terms of the Creative Commons Attribution License (http://creativecommons.org/licenses/by/4.0), which permits unrestricted use, distribution, and reproduction in any medium, provided the original work is properly cited. 
AIF extraction AIFs were obtained by taking mean time courses from LV Lumen ROIs, shown in Figure 2. The regional geometric transfer matrix (GTM) method was applied for PVC [4], using ROIs drawn on either the co-registered MR images or directly onto the last dynamic frame PET images. ROIs covered LV lumen,
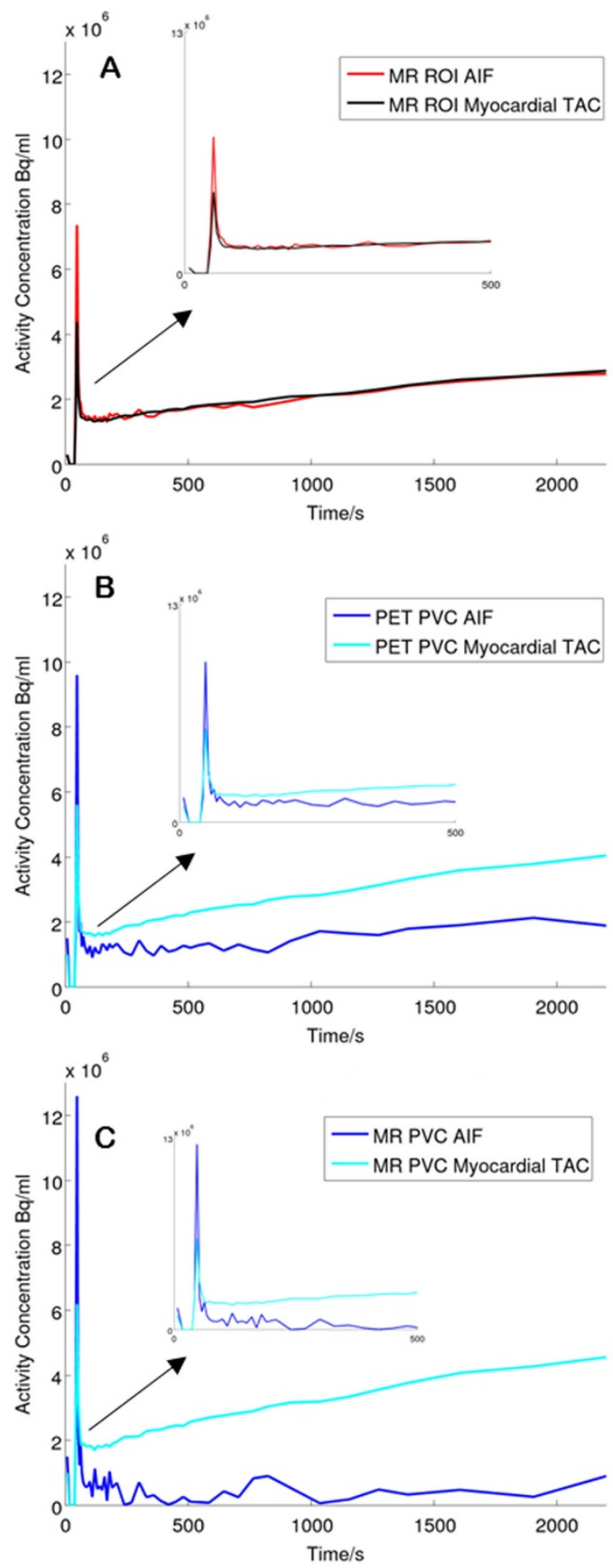

Figure 2 AlFs and TACs derived for single subject using (A) MR ROIs, (B) PET ROls with PVC and (C) MR ROls with PVC. Insets detail first 500s 
Table 1

\begin{tabular}{ccccc}
\hline & \multicolumn{3}{c}{ Glucose metabolism $K_{i}\left(\mathrm{ml} / \mathrm{min} / \mathrm{cm}^{3}\right)$, Mean \pm SD } \\
\cline { 2 - 5 } Without PVC & \multicolumn{2}{c}{ With PVC } \\
\hline Group & PET ROls & MR ROls & PET ROls & MR ROls \\
\hline Untreated & $0.03 \pm 0.01$ & $0.03 \pm 0.01$ & $0.4 \pm 0.3$ & $0.6 \pm 0.2^{*}$ \\
\hline Treated & $0.03 \pm 0.01$ & $0.03 \pm 0.02$ & $0.2 \pm 0.3$ & $0.2 \pm 0.2^{*}$ \\
\hline
\end{tabular}

myocardium, lungs/body and background. Patlak [5] analysis was performed to evaluate glucose metabolism.

Uncorrected AIFs and myocardial TACs produced by manual ROI delineation displayed contamination with myocardial signal. AIFs and myocardial curves became distinguishable if GTM PVC was applied. Only MR-based PVC produced significant differences $(\mathrm{p}<0.05)$ in $\mathrm{K}_{\mathrm{i}}$ values between the treated and untreated groups (see Table 1).

GTM-based PVC gives best results in mice when ROIs are based on MRI data, due to its high-resolution and excellent soft-tissue contrast.

\section{Authors' details}

${ }^{1}$ Wolfson Brain Imaging Centre, University of Cambridge, Cambridge, UK. ${ }^{2}$ Athinoula A Martinos Centre, Harvard University, Cambridge, MA, USA. ${ }^{3}$ Department of Medicine, University of Cambridge, Cambridge, UK. ${ }^{4}$ Department of Physics, University of Cambridge, Cambridge, UK. ${ }^{5}$ Behavioural and Clinical Neurosciences Institute, University of Cambridge, Cambridge, UK.

Published: 29 July 2014

\section{References}

1. Methner C, et al: Riociguat Reduces Infarct Size and Post-Infarct Heart Failure in Mouse Hearts: Insights from MRI/ PET Imaging. PloS One 2013, 8(12):e83910, DOI: 10.1371/journal.pone.0083910.

2. Lucas AJ, et al: Development of a combined microPETÂं-MR system. IEEE Nucl Sci Symp Record 2006, 4:2345-8.

3. Sawiak SJ, et al: MRI reveals brain asymmetry following 6-OHDA lesions in the mouse brain. Proc. ISMRM 2009, 17:1077[http://cds.ismrm.org/protected/09MProceedings/files/01077.pdf].

4. Rousset OG, et al: Correction for partial volume effects in PET: principle and validation. J Nucl Med 1998, 39(5):904-911.

5. Patlak CS, et al: Graphical evaluation of blood-to-brain transfer constants from multiple-time uptake data. J Cereb Blood Flow Metab 1983, 3(1):1-7.

Cite this article as: Evans et al: Combining MRI with PET for partial volume correction improves image-derived input functions in mice. EJNMMI Physics 2014 1(Suppl 1):A84.

\section{Submit your manuscript to a SpringerOpen ${ }^{\circ}$ journal and benefit from:}

- Convenient online submission

- Rigorous peer review

- Immediate publication on acceptance

- Open access: articles freely available online

- High visibility within the field

- Retaining the copyright to your article

Submit your next manuscript at $\boldsymbol{~ s p r i n g e r o p e n . c o m ~}$ 